\title{
Opioid Desensitization: Interactions with G-Protein-Coupled Receptors in the Locus Coeruleus
}

\author{
Christopher D. Fiorillo and John T. Williams \\ The Vollum Institute, Oregon Health Sciences University, Portland, Oregon 97201
}

In rat locus coeruleus (LC) neurons, $\alpha_{2}$ adrenoceptors, $\mu$-opioid and somatostatin receptors all activate the same potassium conductance. Chronic treatment with morphine causes a loss of sensitivity that is specific to the $\mu$-opioid response, with no change in the $\alpha_{2}$ adrenoceptor-mediated response. Acute desensitization induced by opioid, somatostatin, and $\alpha_{2}{ }^{-}$ adrenoceptor agonists was studied in brain slices of rat LC using intracellular recording. A supramaximal concentration of the opioid agonist $\mathrm{Met}^{5}$-enkephalin induced a profound homologous desensitization but little heterologous desensitization to an $\alpha_{2}$-adrenoceptor agonist (UK 14304) or somatostatin. All desensitized currents showed partial recovery. A supramaximal concentration of UK14304 caused a relatively small amount of

Desensitization of receptor-mediated responses attributable to prolonged or excessive exposure to agonist is a widespread phenomenon. Desensitization is of particular interest with respect to the development of tolerance to drugs, in which it can limit the therapeutic utility of many substances. Because of the great efficacy of morphine in the treatment of pain, tolerance to opioids has been the subject of much research. Both the acute and chronic actions of opioids on neurons of the locus coeruleus (LC) have been studied intensely. LC cells express the $\mu$ subtype of opioid receptor, which activates a potassium conductance (Pepper and Henderson, 1980; Williams et al., 1982, 1988) and inhibits adenylate cyclase (Duman et al., 1988; Beitner et al., 1989) through a pertussis toxin-sensitive G-protein (Aghajanian and Wang, 1986). The LC has been proposed to play a central role in the behavioral phenomena of tolerance and withdrawal to opiates (Koob et al., 1992; Maldonado et al., 1992).

In rats treated chronically with morphine, the dose-response curves for full opioid agonists in slices of LC are shifted to the right and the maximal current for the partial agonist normorphine is reduced (Christie et al., 1987). Responses show no recovery over several hours in the slice in the absence of agonist. The decreased opioid response attributable to chronic morphine treatment is homologous, because $\alpha_{2}$-adrenoceptor activation of the same potassium current is unchanged. Whereas the number of opioid receptor-binding sites in the CNS may be reduced marginally by chronic opiate treatment, downregulation does not appear to be responsible for tolerance (Tao et al., 1987; Werling et al., 1989). It therefore appears that the decline in response after

Received Sept. 21, 1995; revised Nov. 8, 1995; accepted Nov. 14, 1995.

This work was supported by National Institutes of Health Grant DA08163. We thank Drs. E. W. McClcskey and B. P. Bean for comments on this manuscript.

Correspondence should be addressed to John T. Williams, The Vollum Institute, L474, Oregon Health Sciences University, 3181 SW Sam Jackson Park Road, Portland, OR 97201.

Copyright (C) 1996 Society for Neuroscience $0270-6474 / 96 / 161479-07 \$ 05.00 / 0$ desensitization. Although little interaction was observed among inhibitory G-protein-coupled receptors, activation of an excitatory receptor had marked effects on inhibitory responses. Muscarinic agonists, which produce an inward current in LC neurons, reduced the magnitude of agonist-induced outward currents and increased both the rate and amount of opioid desensitization. Muscarinic activation did not alter desensitization of $\alpha_{2}$-adrenoceptor responses. Acute desensitization shares several characteristics with the tolerance induced by chronic morphine treatment of animals.

Key words: desensitization; locus coeruleus; brain slices; $\mu$-opioid; $\alpha_{2}$ adrenoceptor; somatostatin; muscarinic

chronic morphine treatment is not caused by a change in the number of receptors or potassium channels.

Results in the LC are consistent with studies in cell lines naturally expressing opioid receptors, in which chronic opioid treatment produces a homologous desensitization of opioid inhibition of activated adenylyl cyclase. These studies generally have concluded that desensitization is caused by uncoupling of opioid receptors from their G-proteins and that downregulation of receptor number is limited and occurs only after uncoupling (Law et al., 1983, 1991; Puttfarcken et al., 1988).

In addition to the tolerance that develops in the LC with prolonged exposure to $\mu$-opioid agonists, acute desensitization occurs in the presence of high concentrations of agonist. It was reported previously that supramaximal concentrations of $\mu$-opioid agonists produced a hyperpolarization that declined over 5 min to $70 \%$ of its peak value and recovered over $-20 \mathrm{~min}$ (Harris and Williams, 1991). This desensitization was found to be primarily homologous with respect to the $\alpha_{2}$ adrenoceptor-mediated hyperpolarization.

The recent cloning of opioid receptors, as well as a G-proteincoupled potassium channel, has made coexpression studies possible. These studies provide an opportunity for examining mechanisms of desensitization under carefully controlled conditions. An understanding of the differences between homologous and heterologous desensitization in the LC may aid in the interpretation of results from more artificial preparations. The purpose of the present study was to characterize the two processes more fully. By measuring drug-induced currents under voltage clamp, we have quantified desensitization better than is possible through voltage measurements. Our results clearly illustrate the homologous nature of $\mu$-opioid desensitization. Whereas little interaction was observed among $\mathrm{G}_{\mathrm{i}}$-coupled receptors, activation of muscarinic receptors had marked effects on agonist-induced outward currents. In particular, we found that $\mu$-opioid desensitization, but 
Figure 1. Desensitization induced by $\mu$-opioid and $\alpha_{2}$-adrenoceptor agonists. $A$, Supramaximal concentrations of the $\mu$-opioid agonist $M E$ and the $\alpha_{2}$ adrenoceptor agonist UK14304 both induced outward currents that declined with time. The decline in the ME-induced current was always much greater than the decline in the UK14304-induced current. Idazoxan $(1 \mu \mathrm{M})$ was superfused to reverse the current induced by UK14304. In all cells, currents were recorded while clamping the membrane at $-60 \mathrm{mV}$. Holding currents ranged from 30 to $-200 \mathrm{pA}$ in the absence of drugs. $B$, The decline in both ME- and UK14304-induced currents was accompanicd by a decline in conductance $(M E, n=17 ; U K 14304, n=$ 7). Current-voltage plots were created at the peak of the current and after its decay (desensitized) by subtracting the raw current-voltage curve in the absence of drug from the raw current-voltage curve in the presence of drug. Current-voltage curves were generated by $200 \mathrm{msec}$ steps of the membrane voltage from a holding potential of $-60 \mathrm{mV}$ to potentials ranging from -60 to $-140 \mathrm{mV}$.
A
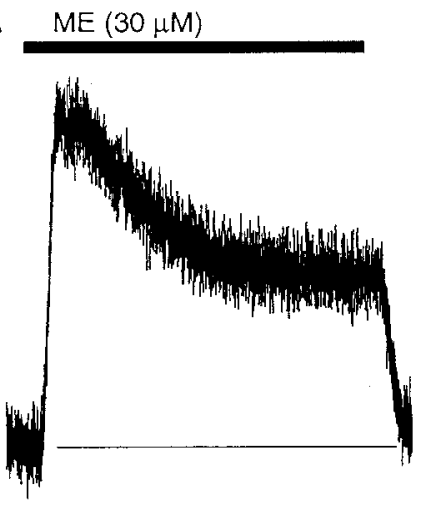

B ME

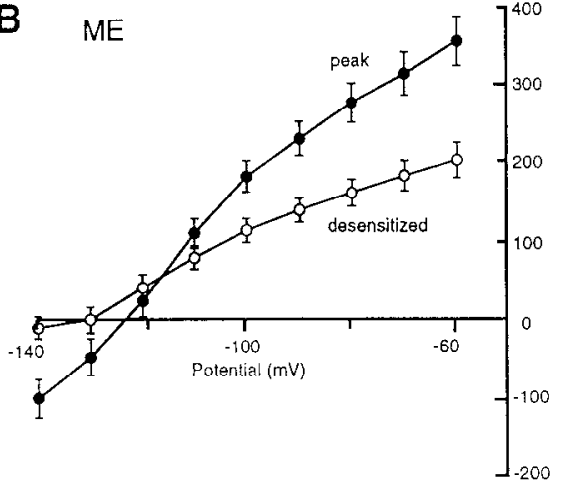

Current $(\mathrm{PA})$

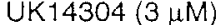
UK
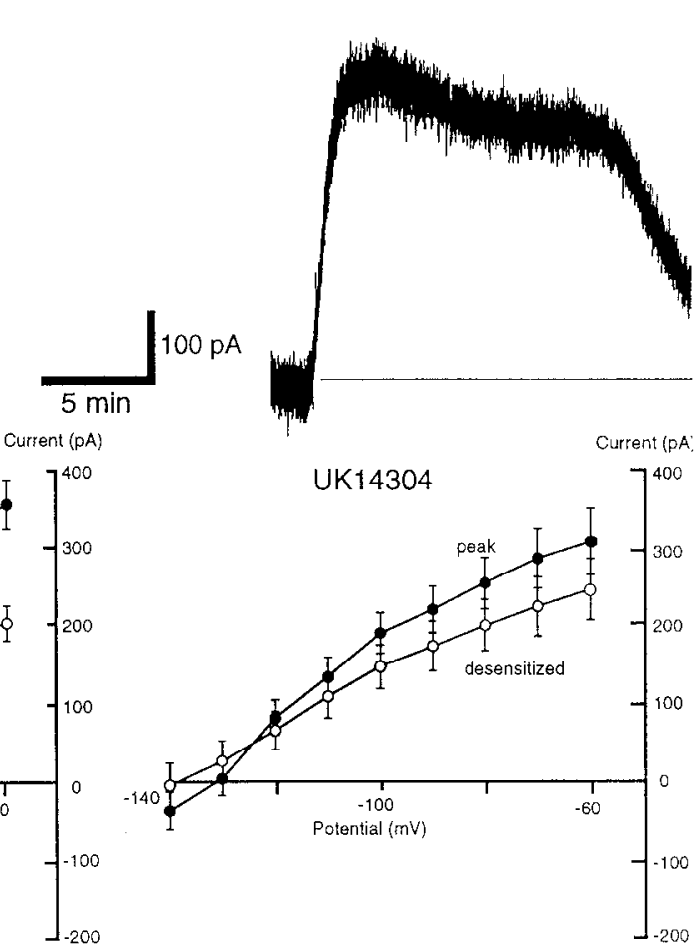

not $\alpha_{2}$-adrenoceptor desensitization, is enhanced by muscarinic agonists.

\section{MATERIALS AND METHODS}

Subjects. Male Wistar rats $(150-200 \mathrm{gm})$, housed according to NIH guidelines, were used for all experiments.

Tissue preparation and recordings. Exact details of the method of slice preparation and recording have been published previously (Williams et al., 1984). Briefly, rats were anesthetized with halothane and killed. Horizontal slices $(300 \mu \mathrm{m}$ thick) containing the LC were cut using a Vibratome and stored in an oxygenated chamber at $35^{\circ} \mathrm{C}$. For recording, a hemisected slice was submerged in a volume of $0.5 \mathrm{ml}$ of artificial CSF, which was superfused at a temperature of $35^{\circ} \mathrm{C}$ at a rate of $1.5 \mathrm{ml} / \mathrm{min}$. The solution was equilibrated with $95 \% \mathrm{O}_{2} / 5 \% \mathrm{CO}_{2}$ and contained (in $\mathrm{mm}$ ): $126 \mathrm{NaCl}, 2.5 \mathrm{KCl}, 1.2 \mathrm{MgCl}_{2}, 2.4 \mathrm{CaCl}_{2}, 1.4 \mathrm{NaH}_{2} \mathrm{PO}_{4}, 25$ $\mathrm{NaHCO}_{3}$, and $11 \mathrm{D}$-glucose. Microelectrodes were filled with $2 \mathrm{M} \mathrm{KCl}$ and had resistances of 25-50 M . Measurement of current and voltage was made with an Axoclamp 2A amplifier (Axon Instruments, Foster City, CA). Membrane currents were recorded in discontinuous voltage-clamp mode with a switching frequency of $3.5-4.5 \mathrm{kHz}$. The potential at the headstage was monitored with a second oscilloscope. Detailed descriptions of the electrical properties of $\mathrm{LC}$ neurons in a slice preparation identical to that used here have been published previously (Williams et al., 1984).

Drugs. DL-2-Amino-5-phosphonovaleric acid (APV), bestatin, $\mathrm{Met}^{5}-$ enkephalin (ME), (-)-scopolamine, somatostatin, and DL-thiorphan were obtained from Sigma (St. Louis, MO). Acetylcholine chloride $(\mathrm{ACh})$, carbachol, hexamethonium chloride, idazoxan, $( \pm)$-muscarine chloride, and UK14304 were from Research Biochemicals (Natick, MA). $\Lambda \mathrm{MP} \Lambda$ was from Tocris Neuramin (Bristol, UK).

Drug application. Drugs were applied by superfusion. In all experiments, ME was used in combination with the peptidase inhibitors bestatin $(20 \mu \mathrm{M})$ and thiorphan $(2 \mu \mathrm{M})$. ME was chosen because it washes (or is degraded) quickly even at high concentrations. ME has been shown to act exclusively at $\mu$-opioid receptors on LC neurons (Williams and North, 1984), and we observed identical results with the selective $\mu$-opioid agonist $\left[\mathrm{D}-\mathrm{Ala}^{2}, \mathrm{~N}-\mathrm{Me}-\mathrm{Phe}^{4}, \mathrm{Gly}-\mathrm{ol}^{5}\right]$ enkephalin in several cells. The nicotinic antagonist hexamethonium $(400 \mu \mathrm{M})$ was applied in experiments with carbachol or ACh. In experiments with AMPA, antagonists were used to block the actions of released endogenous transmitters. These included the NMDA-receptor antagonist APV $(30 \mu \mathrm{M})$, the $\alpha_{2^{-}}$ adrenoceptor antagonist idazoxan $(1 \mu \mathrm{M})$, and the muscarinic antagonist scopolamine $(1 \mu \mathrm{M})$. None of the above antagonists has a measurable effect when applied alone.

Data analysis. Values are given as arithmetic mean \pm SEM. For statistical analysis, paired and unpaired $t$ tests were performed. Differences in data for which $p<0.05$ were taken to be significant. Each experiment of a given protocol was performed on a separate animal. All time constants were obtained by fitting the data to a single exponential using iterations of the sum of squared errors.

\section{RESULTS}

\section{Desensitization of opioid responses}

Superfusion of ME $(30 \mu \mathrm{M})$ caused a peak outward current of 417 $\pm 19 \mathrm{pA}(n=72)$. The current decayed with a time constant of 3.1 $\pm 0.2 \mathrm{~min}(n=17)$ to a stable level of $53 \pm 2 \%(n=17)$ of the peak amplitude (Fig. 1A). No correlation was found between the maximal amplitude of the current and either the rate or amount of desensitization. Multiple applications of ME could be applied to a single cell with little change in the rate or amount of desensitization.

To examine the recovery of the outward current, an approximately half-maximal concentration of $\mathrm{ME}(0.3-1 \mu \mathrm{M})$ was perfused until a steady-state current $(214 \pm 21 \mathrm{pA})$ was reached (Fig. $2)$. The high concentration of $\mathrm{ME}(30 \mu \mathrm{M})$ then was perfused for 5 min before switching back to the low concentration. The current peaked and declined to $67 \pm 2 \%(n=19)$ of the peak valuc at the end of the $5 \mathrm{~min}$. Immediately after washing of the high concentration, the current produced by the low concentration of ME was reduced to $14 \pm 4 \%(n=19)$ of its initial level. With continuous perfusion of the low concentration of $\mathrm{ME}$, the current recovered to $64 \pm 4 \%(n=19)$ of control $20 \mathrm{~min}$ after washout of the high concentration of ME. ME then was completely washed out. Subsequent applications of the low concentration of ME, 10-30 min later, showed greater recovery $(77 \pm 3 \% ; n=13)$ and were 


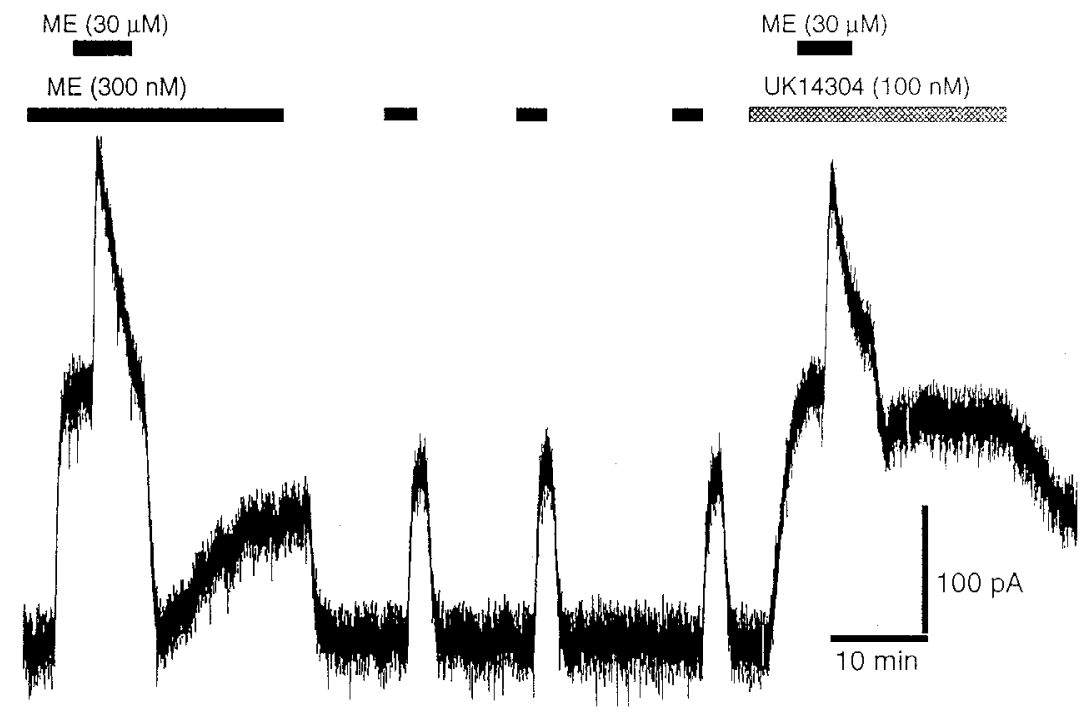

Figure 2. Homologous and heterologous desensitization by $M E$. The response to a half-maximal concentration of ME was decreased on average to $14 \%$ of its initial value after a 5 min exposure to a supramaximal concentration of ME. By contrast, the same protocol reduced the response to the $\alpha_{2}$-adrenoceptor agonist $U K 14304$ to only $86 \%$ of control. Both desensitized currents recovered. reproducible over time. Full recovery was never observed to low concentrations, although subsequent application of the high concentration $(30 \mu \mathrm{M})$ produced currents that were $\geq 95 \%$ of the original peak in 9 of 21 cells, with an average of $86 \pm 3 \%$ after $\geq 20 \mathrm{~min}$. This is significantly greater recovery than that observed to low concentrations (paired $t$ test, $p<0.05 ; n=8$ ), suggesting a long-lasting rightward shift in the dose-response curve.

Time constants of recovery were calculated for those cells in which the current induced by the low concentration of ME reached a plateau before washout (Fig. 2). The average time constant for these cells was $7.5 \pm 1.1 \mathrm{~min}(n=11)$. In eight other cells, the recovering current did not reach a clear plateau before the ME was washed $\sim 20$ min after washing the high concentration of ME. Prolonged application ( $\geq 10 \mathrm{~min}$ ) of a low concentration of $\mathrm{ME}$ revealed a slight rundown (see Desensitization to low concentrations of agonist).

\section{Desensitization of $\alpha_{2}$-adrenoceptor responses}

To examine the degree to which opioid desensitization is heterologous, the same experiment as above was carried out substituting a submaximal concentration of UK14304, a selective $\alpha_{2}$ adrenoceptor agonist, for the low concentration of ME (Fig. 2). UK14304 (100 nM) initially caused an outward current of $329 \pm 49$ pA $(n=9)$. A 5 min application of $\mathrm{ME}(30 \mu \mathrm{M})$ in the continued presence of UK14304 produced a peak current of $454 \pm 56$ pA (measured from the original holding current) that declined to 81 $\pm 3 \%(n=9)$ of the peak after $5 \mathrm{~min}$. After the ME had washed out, the UK14304 current was reduced to $86 \pm 3 \%(n=9)$ of its initial value, and after $20 \mathrm{~min}$ it had recovered to $96 \pm 2 \%(n=$ $7)$. For those cells in which the rate of recovery could be calculated, the time constant was $4.5 \pm 1.0 \mathrm{~min}(n=7)$. Prolonged application of low concentrations of UK14304 alone revealed a slight decay of the current (see Desensitization to low concentrations of agonist).

Desensitization to a high dose of UK14304 was also studied. UK14304 $(3 \mu \mathrm{M})$ produced a peak current of $373 \pm 43 \mathrm{pA}$ that declined to $78 \pm 3 \%(n=12)$ of the peak after $10-15 \mathrm{~min}$ (Fig. $1 A)$. The current decayed with a time constant of $7.2 \pm 1.3 \mathrm{~min}(n$ $=7)$ in those cells in which the desensitizing current reached a plateau, compared with $3.1 \pm 0.2 \min (n=17)$ for $\mathrm{ME}(30 \mu \mathrm{M})$. The UK14304 response was terminated by superfusion with the selective $\alpha_{2}$-adrenoceptor antagonist idazoxan $(1 \mu \mathrm{M})$. Reversal of the response with an antagonist was necessary because of the slow washout of UK14304 and precluded any further experiments with $\alpha_{2}$-adrenoceptor agonists in that slice. Once the current had returned to basal levels ( $\sim 15 \mathrm{~min}$ after perfusion of idazoxan), a low concentration of ME gave a response that was $76 \pm 9 \%(n=$ 5) of the pre-UK14304 level. Subsequent exposures to ME in three cells showed no further change.

\section{Desensitization of somatostatin responses}

Somatostatin activates the same potassium current as $\mu$-opioid and $\alpha_{2}$-adrenoceptor agonists in the LC. Somatostatin $(3-6 \mu \mathrm{M})$ produced a maximal peak outward current of $313 \pm 48 \mathrm{pA}$. The decay of the current was variable but averaged $62 \pm 9 \%(n-6)$ of the peak after $\sim 10 \mathrm{~min}$ and had a time constant of $1.6 \pm 0.6$ $\min (n=3$; data not shown). Application of ME $(30 \mu \mathrm{M})$ immediately after desensitization to somatostatin revealed little reduction in the peak response and no apparent occlusion of $\mathrm{ME}$ desensitization in three cells, suggesting that somatostatin desensitization is primarily homologous with respect to the opioid response. This is in agreement with results in guinea pig submucosal neurons (Shen and Surprenant, 1993).

Heterologous desensitization of the somatostatin response by $\mathrm{ME}$ also was examined. Somatostatin (300-600 nM) induced a current of $152 \pm 12 \mathrm{pA}$ that was reduced to $77 \pm 4 \%(n=12)$ immediately after a 5 min application of ME (30 $\mu \mathrm{M}$; Fig. 3$)$. The somatostatin current recovered from heterologous desensitization in three cells, suggesting that the smaller response after ME was not attributable solely to homologous desensitization to somatostatin. In any case, heterologous desensitization of the somatostatin response by opioids is much less than the homologous desensitization to opioids.

\section{Desensitization to low concentrations of agonist}

A small amount of desensitization also was observed in the continuous presence of low concentrations of both ME and UK14304 (data not shown). ME (300 nM) produced a peak current of $292 \pm$ $50 \mathrm{pA}$ that declined to $87 \pm 4 \%$ (paired $t$ test, $p<0.02 ; n=5$ ) of the peak after $10 \mathrm{~min}$. UK14304 (25-100 nM; a half-maximal current is produced by $\sim 25 \mathrm{nM}$ ) caused a peak current of $333 \pm$ $43 \mathrm{pA}$ that declined to $88 \pm 2 \%$ (paired $t$ test, $p<0.01 ; n=8$ ) of the peak after $\sim 20 \mathrm{~min}$. This is significantly less desensitization than was observed to the high concentration of UK14304 (3 $\mu \mathrm{M}$, 
Figure 3. ME causes little cross-desensitization of somatostatin responses. The response to low concentrations of Somatostatin was reduced to an average of $77 \%$ of control after a $5 \mathrm{~min}$ application of a supramaximal concentration of $M E$.

unpaired $t$ test, $p<0.05$ ). It appears that desensitization can occur at lower concentrations, but the rate and/or the maximum degree of desensitization are less. The decline in both the opioid and $\alpha_{2}$-adrenoceptor currents, therefore, is dependent on the concentration of agonist, even at concentrations greater than that needed to induce a maximal current.

\section{Desensitization corresponds to decline in potassium conductance}

Current-voltage relationships were examined at the peak current and after desensitization to high concentrations of $\mathrm{ME}(30 \mu \mathrm{M})$ and UK14304 $(3 \mu \mathrm{M})$. Both were qualitatively similar, showing a decrease in conductance with desensitization but little shift in reversal potential (Fig. $1 B$ ). The $\mathrm{ME}$-induced slope conductance between -60 and $-90 \mathrm{mV}$ declined from a maximum of $4.1+0.4$ $\mathrm{nS}$ to a stable level of $2.2 \pm 0.3 \mathrm{nS}(7-15 \mathrm{~min})$, with an average decline of $1.9 \pm 0.2 \mathrm{nS}(n=17)$. The conductance induced by UK14304 was initially $3.0 \pm 0.5 \mathrm{nS}$ and was reduced to $2.4 \pm 0.3$ $\mathrm{nS}$ after 10-15 min of perfusion, with an average decrease of 0.6 $\pm 0.2 \mathrm{nS}(n=7)$. The decline in conductance was significantly greater for ME than for UK14304 (unpaired $t$ test, $p<0.001$ ). The difference in the reversal potentials before and after desensitization almost certainly is attributable to the poor voltage control in horizontal slices. No shift in reversal potential occurs with opioid desensitization in coronal slices (Harris and Williams, 1991), in which voltage control is significantly greater than in horizontal slices (Travagli et al., in press).

\section{Interactions with muscarinic agonists}

Having examined interactions among receptors that couple to activation of $\mathrm{K}^{+}$channels, we next investigated interactions of these receptors with an excitatory $\mathrm{G}$-protein-coupled receptor. Muscarine produces an inward current in LC neurons at all potentials between -40 and $-140 \mathrm{mV}$ (Fig. $4 B$ ) (Shen and North, 1992). The inward current is accompanied by little change in conductance over this potential range, and it has been proposed to result from an increase. in a nonselective cation conductance and a decrease in potassium conductance (Shen and North, 1992). However, the G-protein and second-messenger systems involved remain unknown.

Muscarine $(10 \mu \mathrm{M})$, carbachol $(10-20 \mu \mathrm{M})$, and acetylcholine
(1.0-1.5 mM) were used to elicit currents ranging from -40 to $-234 \mathrm{pA}$, with a mean of $-103 \pm 12(n=20)$. The currentvoltage curve between -60 and $-140 \mathrm{mV}$ (Fig. $4 B$ ) was well fit by a straight line with a slope of $1.0 \pm 0.2 \mathrm{nS}(n=19)$. Muscarinic agonists decreased the peak amplitude of opioid-induced currents (Fig. $4 A$ ) to $67 \pm 7 \%$ of control (paired $t$ test, $p<0.01 ; n=10$ ) and UK14304-induced currents to $65 \%$ of control (unpaired $t$ test, $p<0.05 ; n=8$ ). Internal controls could not be performed with UK14304 because of its very slow rate of washing from the tissue. However, carbachol-induced inward currents were found to be approximately twice as large as control in the presence of UK14304 (3 $\mu \mathrm{M})$ in two cells.

Muscarinic activation was found to increase both the rate and amount of $\mu$-opioid desensitization (Fig. 4A) without affecting $\alpha_{2}$-adrenoceptor desensitization. In the presence of muscarinic agonists, the ME-induced current declined to $36 \pm 4 \%(n=12)$ of the pcak value versus $57 \pm 2 \%(n=12)$ of the peak in control (unpaired $t$ test, $p<0.001$; paired $t$ test, $p<0.02 ; n=6$ ). The current decayed with a time constant of $1.9 \pm 0.2 \min (n=10)$ in the presence of muscarinic agonists compared to $3.4 \pm 0.4 \mathrm{~min}(n$ $=10$ ) in control (unpaired $t$ test, $p<0.01$ ). As in control, the ME-induced desensitization observed at $-60 \mathrm{mV}$ in the presence of muscarinic agonists resulted exclusively from a decline in conductance that reversed polarity near $E_{\mathrm{k}}$ (Fig. $4 B$ ). The peak ME conductance measured from -60 to $-90 \mathrm{mV}$ was $3.5 \pm 0.7 \mathrm{nS}$, and the desensitized conductance was $1.6 \pm 0.3 \mathrm{nS}$, with an average change of $-2.0 \pm 0.6 \mathrm{nS}(n=7)$. In the presence of muscarinic agonists, the current measured after a 10-15 min exposure to UK14304 $(3 \mu \mathrm{M})$ was $83 \pm 3 \%(n=8)$ of the peak (data not shown), which was unchanged from control.

Because voltage control is known to be poor in horizontal slices of LC (Oleskevich et al., 1993; Travagli et al., 1995), we considered the possibility that the effects of muscarinic agonists werc secondary to depolarization of poorly clamped dendrites. To test this, ME desensitization was examined in the presence of the selective glutamate agonist AMPA. Concentrations of AMPA ranging from 200 to $350 \mathrm{nM}$ elicited an average current of $-151 \pm$ $20 \mathrm{pA}(n=8)$. In the presence of AMPA, the peak amplitude (paired $t$ test, $p=0.14 ; n=5$ ), the amount of desensitization to 


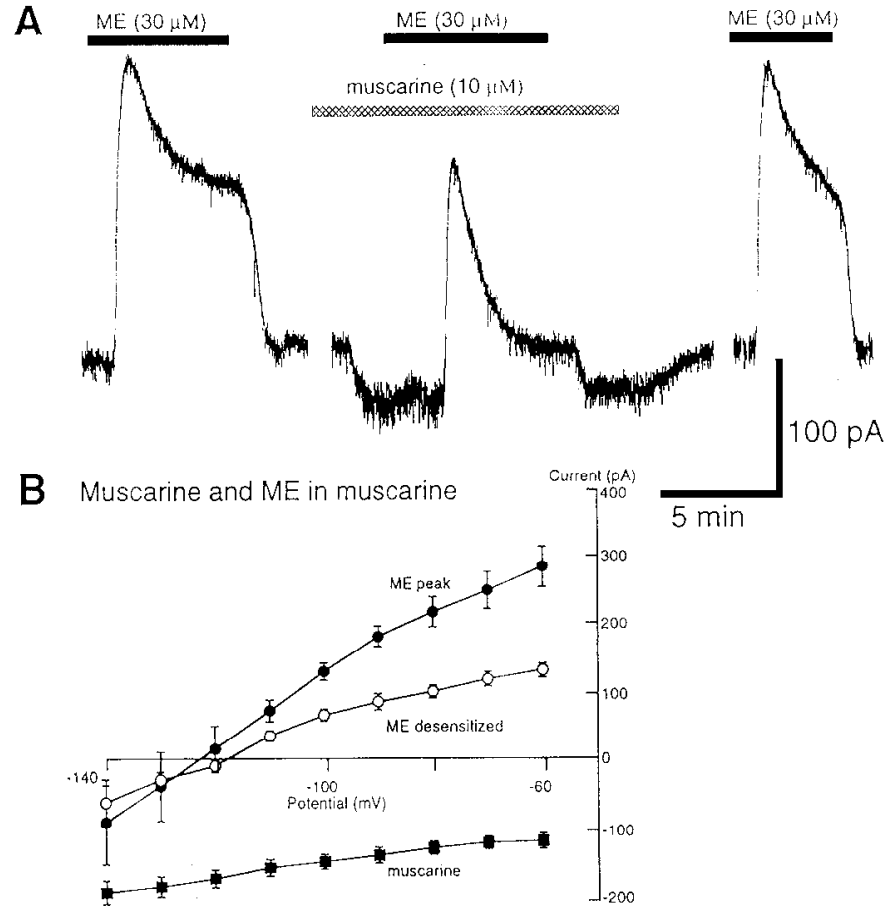

Figure 4. Muscarine reduces the magnitude of agonist-induced currents while specifically enhancing opioid desensitization. $A$, Muscarine decreases the magnitude of ME-induced currents and increases the rate and amount of desensitization. All traces were obtained from the same cell in the order shown, with the applications of $M E$ separated by $\sim 25 \mathrm{~min}$. Carbachol and acetylcholine had the same effect as muscarine. Muscarinic agonists also decreased the magnitude of currents induced by the $\alpha_{2}-$ adrenoceptor agonist UK14304 but did not affect desensitization to UK14304 (data not shown). $B$, Current-voltage relationships of the conductance activated hy muscarinic agonists $(n=19)$, as well as the peak and desensitized conductance induced by $\mathrm{ME}$ ( $M E$ peak, ME desensitized) in the presence of muscarinic agonists (muscarine; $n=7$ ).

ME (30 $\mu \mathrm{M}$; paired $t$ test, $p>0.6 ; n=5$ ), and the time constant (paired $t$ test: $p>0.6, n=3$; unpaired: $p>0.6, n=6$ control, $n$ $=5$ in AMPA) were not significantly different from control (data not shown). The amount of desensitization in muscarine compared with control in the same cell $(n=6)$ was significantly greater (unpaired $t$ test, $p<0.05$ ) than that in AMPA compared with internal control $(n=5)$. Furthermore, if the effect on desensitization was voltage-dependent, then the amount and rate of desensitization should correlate with the size of the inward current. No correlation was found between the amplitude of the muscarine- or AMPA-induced currents and the size of the effect on the time constant or amount of ME desensitization, or the peak current.

\section{DISCUSSION}

Voltage-clamp recordings were used to study acute desensitization to high concentrations of $\mu$-opioid and $\alpha_{2}$-adrenoceptor agonists. A supramaximal concentration of the $\mu$-opioid agonist ME induced an outward current that declined to $50 \%$ of the peak, whereas the current produced by an analogous concentration of the $\alpha_{2}$-adrenoceptor agonist UK14304 declined to only $80 \%$ of the peak. Muscarinic agonists increased both the rate and amount of desensitization to $\mathrm{ME}$ but did not alter desensitization to UK14304. Desensitization to ME was primarily homologous. Both the homologous and heterologous components of desensitization recovered over $10-30 \mathrm{~min}$. The lack of cross-desensitization of the somatostatin response provides particularly compelling evidence for the homologous nature of opioid desensitization considering that somatostatin receptors are related closely in primary structure to opioid receptors. More convincing evidence comes from studies in undifferentiated SH-SY5Y human neuroblastoma cells, which express both $\mu$ - and $\partial$-opioid receptors yet show only homologous desensitization (Prather et al., 1994).

\section{Mechanism of opioid desensitization}

The mechanism of acute opioid desensitization in the LC has been examined previously, with few positive results. The phosphatase inhibitor microcystin was found to prolong the time course of recovery from desensitization (Osborne and Williams, 1995). $\beta$-Chlornaltrexamine, an irreversible opioid-receptor antagonist, reduced the maximum hyperpolarization but did not reduce the relative amount of desensitization (Harris and Williams, 1991). This suggests that desensitization occurs locally at the level of single receptors and does not depend on the number of functional receptors or the magnitude of the response.

Results in the LC as well as in cell lines show that the amount of desensitization of opioid receptors depends on the concentration of agonist, its affinity, and its intrinsic efficacy (Law et al., 1983). The amount of desensitization, therefore, is correlated with the amount of time the receptor spends in an active state. The same is true for homologous desensitization of the $\beta_{2}$ adrenoceptor (for review, see Dohlman et al., 1991; Lohse, 1993). In its active conformation, the $\beta_{2}$ receptor is a substrate for phosphorylation by a G-protein-coupled receptor kinase (GRK). Phosphorylation allows the protein $\beta$-arrestin to bind to the receptor and thereby prevent coupling to $G$-proteins. Opioid desensitization is also caused by a functional uncoupling of receptors from G-proteins (Puttfarcken et al., 1988; Law et al., 1991).

Multiple GRKs and arrestins have been discovered and are known to act on other receptors in vitro (Craft and Whitmore, 1995; Gurevich et al., 1995; Premont et al., 1995). In particular, the $m_{2}$-muscarinic receptor, which couples to the same intracellular effectors as opioid receptors, undergoes agonist-dependent desensitization and phosphorylation by a GR in vitro and in vivo (Kameyama et al., 1994; Tsuga et al., 1994). It was shown recently that the uncoupling of atrial $\mathrm{m}_{2}$-muscarinic receptors from $\mathrm{K}^{+}$ channels, which is very similar to opioid desensitization in both time constant and extent, is absent in patch-clamp configurations in which the intracellular solution is lost (Shui et al., 1995). Desensitization is reestablished in outside-out patches when GRK2 and ATP are included in the pipette.

\section{Mechanism of $\alpha_{\mathbf{2}}$-adrenoceptor desensitization}

It seems unlikely that $\alpha_{2}$-adrenoceptor desensitization in the LC occurs via a GRK-mediated mechanism. Adrenoceptor desensitization is heterologous, since both the opioid and the $\alpha_{2^{-}}$ adrenoceptor responses are reduced to a similar degree. The most notable feature of $\alpha_{2}$-adrenoceptor desensitization in the LC is its slow and limited nature. In guinea pig submucosal neurons, the $\alpha_{2}$ adrenoceptor-activated outward potassium current does not desensitize (Shen and Surprenant, 1993). Whereas some subtypes of cloned $\alpha_{2}$ adrenoceptors are known to desensitize quite extensively, others do not (Kurose and Lefkowitz, 1994).

\section{Coexpression studies in Xenopus oocytes}

Several recent studies have described the coupling of coexpressed $\mu$-opioid receptors and $\mathrm{G}$-protein-coupled potassium channels in Xenopus oocyles; homologous desensitization was not observed (Chen and Yu, 1994; Kovoor et al., 1995; Mestek et al., 1995). 
Kovoor et al. (1995) reported the slow inactivation $(\tau=15 \mathrm{~min})$ of the potassium current coupled to coexpressed $\mu$-opioid and 5-HT-1A receptors in Xenopus oocytes. The current decayed with the same time constant whether induced by agonist, GTP $\gamma \mathrm{S}$, or high potassium and was resistant to manipulations of calcium and kinase activity. Slow inactivation of potassium channels could underlie the heterologous component of desensitization in the LC. However, Kovoor et al. (1995) reported that extrapolation of the decay exponential to $\tau=\infty$ revealed complete loss of agonistinduced current. In the LC, currents induced by supramaximal concentrations of opioids always decayed to steady-state levels of $-50 \%$ of the peak current, whereas $\alpha_{2}$ adrenoceptor-induced currents decayed to a plateau of $80 \%$ of the peak after 15 min. In addition, whereas Kovoor et al. (1995) found that the rate of decay of the current was independent of the size of the current or the concentration of agonist, we found that both opioid and $\alpha_{2}$-adrenoceptor desensitization was dose-dependent. It is therefore unlikely that the same potassium-channel inactivation observed in oocytes accounts for a significant amount of the heterologous component of agonist-induced desensitization in the LC.

\section{Enhancement of opioid desensitization by muscarine}

Muscarine causes an inward current in LC neurons via activation of a receptor of uncertain pharmacology (Egan and North, 1985; Shen and North, 1992) (for review, see Caulfield, 1993). The inward current appears to be caused by activation of a nonselective cation conductance and, possibly, inhibition of a potassium conductance (Shen and North, 1992). Neither buffering of inter nal calcium (Shen and North, 1992; Osborne and Williams, 1995) nor application of phorbol esters altered or mimicked opioid desensitization or the muscarine current (G. Harris and J. Williams, unpublished observations).

The $\beta \gamma$ subunits of $\mathrm{G}$-proteins are involved in targeting of some GRKs to their substrates (Haga and Haga, 1992; Pitcher et al., 1992; Kameyama et al., 1993). If opioid desensitization involves a receptor kinase, then the $\beta \gamma$ subunits freed by activation of muscarinic receptors might enhance receptor desensitization by increasing the effective concentration of GRKs at the receptor. If this is the case, activation of many if not all G-protein-coupled receptors would be expected to enhance desensitization of opioid receptors and perhaps other receptors.

The observed facilitation of opioid desensitization by muscarine does not necessarily indicate an effect on the actual process of agonist-induced homologous receptor desensitization. Because of the receptor reserve, a large number of functional opioid receptors must be uncoupled from $\mathrm{K}^{+}$channels before a reduction in the maximal current is observed (Christie et al., 1987; Osborne and Williams, 1995). Much of the receptor desensitization, therefore, has already occurred by the time a decline in current is measured. If muscarine acts to uncouple opioid receptors independent of opioid agonists, thereby decreasing the number of functional receptors and the receptor reserve, it is possible that a greater decay in the opioid-induced current would be observed in the presence of muscarine without a change in the amount of homologous receptor desensitization. We found that muscarine decreases the magnitude of the outward current induced by both opioid and $\alpha$,-adrenoceptor agonists. However, decreasing the coupling efficiency would not be expected to change the observed rate of decay. The faster time constant, therefore, suggests that muscarinic activation facilitates the agonist-induced functional uncoupling of opioid receptors from their effectors.

\section{Comparison of acute and chronic desensitization}

The acute desensitization examined here shares a number of characteristics with chronic tolerance to opiates in the LC. Both are primarily homologous, with the opioid dose-response curves shifted to the right by opioid treatment and the maximum response to the partial agonist normorphine significantly reduced. The acute desensitization protocol used here was estimated to produce a greater loss of functional receptors $(90 \%$ after $5 \mathrm{~min}$; Osborne and Williams, 1995) than the chronic morphine treatment (75\%; Christie et al., 1987). This may be attributable in part to the greater efficacy of full agonists in producing desensitization (Law et al., 1983; Harris and Williams, 1991).

The only marked difference between the acute and chronic treatments is the rate of recovery. Whereas acutely treated cells show recovery of the opioid response over 20-30 min even in the presence of low concentrations of agonist, cells from chronically treated animals show no recovery over several hours in the slice in the absence of agonist (Christie et al., 1987). However, recovery from acute desensitization is not complete. Whereas the response to high concentrations of ME sometimes showed full recovery, the response to low concentrations never approached full recovery. This is consistent with a long-lasting rightward shift in the doseresponse curve, as observed in chronically treated animals. It seems doubtful that this shift, measured over $\sim 45$ min, was attributable exclusively to an agonist-independent rundown of responses. Harris and Williams (1991) found that less acutc desensitization is observed after either acute desensitization or chronic morphine treatment. It therefore appears that acute desensitization may produce long-lasting changes in the response to opioids that at least superficially are similar to the changes seen in chronically treated animals. Considering the incomplete recovery from acute desensitization and the lesser amount of desensitization produced by chronic morphine, it is not clear that there is any qualitative difference in desensitization caused by acute treatment of cells and chronic treatment of animals.

\section{REFERENCES}

Aghajanian GK, Wang Y-Y (1986) Pertussis toxin blocks the outward currents evoked by opiate and $\alpha_{2}$-agonists in locus coeruleus neurons. Brain Res 371:390-394.

Beitner DB, Duman RS, Nestler EJ (1989) A novel action of morphine in the rat locus coeruleus: persistent decrease in adenylate cyclase. Mol Pharmacol 35:559-564.

Caulfield MP (1993) Muscarinic receptors: characterization, coupling and function. J Pharmacol Exp Ther 58:319-379.

Chen Y, Yu L (1994) Differential regulation by cAMP-dependent protein kinase and protein kinase $\mathrm{C}$ of the $\mu$ opioid receptor coupling to a G protein-activated $\mathrm{K}^{+}$channel. J Biol Chem 269:7839-7842.

Christie MJ, Williams JT, North RA (1987) Ccllular mechanisms of opioid tolerance: studies in single brain neurons. Mol Pharmacol 32:633-638.

Craft CM, Whitmore DH (1995) The arrestin superfamily: cone arrestins are a fourth family. FEBS Lett 362:247-255.

Dohlman HG, Thorner J, Caron MG, Lefkowitz RJ (1991) Model systems for the study of seven-transmembrane receptors. Annu Rev Biochem 60:653-688.

Duman RS, Tallman JF, Nestler EJ (1988) Acute and chronic opiateregulation of adenylate cyclase in brain: specific effects in locus coeruleus. J Pharmacol Exp Ther 246:1033-1039.

Egan TM, North RA (1985) Acetylcholine acts on $\mathrm{M}_{2}$-muscarinic receptors to excite rat locus coeruleus neurones. Br J Pharmacol 85:733-735.

Gurevich VV, Dion SB, Onorato JJ, Ptasienski J, Kim CM, Sterne-Marr R, Hosey MM, Benovic JL (1995) Arrestin interactions with G protein-coupled receptors: direct binding studies of wild type and mutant arrestins with rhodopsin, $\beta_{2}$-adrenergic, and $\mathrm{M}_{2}$ muscarinic cholinergic receptors. J Biol Chem 270:720-731. 
Haga K, Haga $T$ (1992) Activation by $G$ protein $\beta \gamma$ subunits of agonistor light-dependent phosphorylation of muscarinic acetylcholine receptors and rhodopsin. J Biol Chem 267:2222-2227.

Harris GC, Williams JT (1991) Transient homologous $\mu$-opioid receptor desensitization in rat locus coeruleus neurons. J Neurosci 11:2574-2581.

Kameyama K, Haga K, Haga T, Kontani K, Katada T, Fukada Y (1993) Activation by $G$ protein $\beta \gamma$ subunits of $\beta$-adrenergic and muscarinic receptor kinase. J Biol Chem 268:7753-7758.

Kameyama K, Haga K, Haga T, Moro O, Sadée W (1994) Activation of a GTP-binding protein and a GTP-binding-protein-coupled receptor kinase ( $\beta$-adrenergic receptor kinase- 1 ) by a muscarinic receptor $\mathrm{m} 2$ mutant lacking phosphorylation sites. Eur J Biochem 226:267-276.

Koob GF, Maldonado R, Stinus L (1992) Neural substrates of opiate withdrawal. Trends Neurosci 5:186-191.

Kovoor A, Henry DJ, Chavkin C (1995) Agonist-induced desensitization of the mu opioid receptor-coupled potassium channel (GIRK1). J Biol Chem 270:589-595.

Kurose H, Lefkowitz RJ (1994) Differential desensitization and phosphorylation of three cloned and transfected $\alpha_{2}$-adrenergic receptor subtypes. J Biol Chem 269:10093-10099.

Law PY, Hom DS, Loh HH (1983) Opiatc receptor down-rcgulation and desensitization in neuroblastoma $\times$ glioma NG108-15 hybrid cells are two separate cellular adaptation processes. Mol Pharmacol 24:413-424.

Law PY, Hom DS, Loh HH (1991) Effect of chronic D-Ala ${ }^{2}, \mathrm{D}-\mathrm{Leu}^{5}-$ enkephalin or pertussis toxin treatment on the high-affinity state of delta opioid receptor in neuroblastoma $\times$ glioma NG108-15 hybrid cells. J Pharmacol Exp Ther 256:710-716.

Lohse MJ (1993) Molecular mechanisms of membrane receptor desensitization. Biochim Biophys Acta 1179:171-188.

Maldonado R, Stinus L, Gold LH, Koob GF (1992) Role of different brain structures in the expression of the physical morphine withdrawal syndrome. J Pharmacol Exp Ther 261:669-677.

Mestek A, Hurley JH, Bye LS, Campbell AD, Chen Y, Tian M, Liu J, Schulman H, Yu L (1995) The human $\mu$ opioid receptor: modulation of functional descnsitization by calcium/calmodulin-dependent protein kinase and protein kinase C. J Neurosci 15:2396-2406.

Oleskevich S, Clements JD, Williams JT (1993) Opioid-glutamate interactions in rat locus coeruleus neurons. J Neurophysiol 70:933-937.

Osborne PB, Williams JT (1995) Characterization of acute homologous desensitization of $\mu$-opioid receptor-induced currents in locus coeruleus neurons. Br J Pharmacol 115:925-932.

Pepper CM, Henderson G (1980) Opiates and opioid peptides hyperpolarize locus coeruleus neurons in vitro. Science 209:394-395.

Pitcher JA, Inglese J, Higgins JB, Arriza JL, Casey PJ, Kim C, Benovic JL, Kwatra MM, Caron MG, Lefkowitz RJ (1992) Role of $\beta \gamma$ subunits of
$\mathrm{G}$ proteins in targeting the $\beta$-adrenergic receptor kinase to membranebound receptors. Science 257:1264-1267.

Prather PL, Tsai AW, Law PY (1994) Mu and delta opioid receptor desensitization in undifferentiated human neuroblastoma SHSY5Y cells. J Pharmacol Exp Ther 270:177-184.

Premont RT, Inglese J, Lefkowitz RJ (1995) Protein kinases that phosphorylatc activated $G$ protein-coupled receptors. FASEB J 9:175-182.

Puttfarcken PS, Werling LL, Cox BM (1988) Effects of chronic morphine exposure on opioid inhibition of adenylyl cyclase in $7315 \mathrm{c}$ cell membranes: a useful model for the study of tolerance at $\mu$ opioid receptors. Mol Pharmacol 33:520-527.

Shen K-Z, North RA (1992) Muscarine increases cation conductance and decreases potassium conductance in rat locus coeruleus neurones. J Physiol (Lond) 455:471-485.

Shen K-Z, Surprenant A (1993) Somatostatin-mediated inhibitory postsynaptic potential in sympathetically denervated guinea-pig submucosal neurones. J Physiol (Lond) 470:619-635.

Shui Z, Boyett MR, Zang W-J, Haga T, Kameyama K (1995) Receptor kinase-dependent desensitization of the muscarinic $\mathrm{K}^{+}$current in rat atrial cells. J Physiol (Lond) 487:359-366.

Tao P-L, Law P-Y, Loh IIII (1987) Decrease in delta and mu opioid receptor binding capacity in rat brain after chronic etorphine treatment. J Pharmacol Exp Ther 240:809-816.

Travagli RA, Dunwiddie TV, Williams JT (1995) Opioid inhibition in the locus coeruleus. J Neurophysiol 74:519-528.

Travagli RA, Wessendorf M, Williams JT (1996) The dendritic arbor of locus coeruleus neurons contributes to opioid inhibition. J Neurophysiol, in press.

Tsuga H, Kameyama K, Haga T, Kurose H, Nagao T (1994) Sequestration of muscarinic acetylcholine receptor $\mathrm{m} 2$ subtypes: facilitation by $\mathrm{G}$ protein-coupled receptor kinase (GRK2) and attenuation by a dominant-negative mutant of GRK2. J Biol Chem 269:32522-32527.

Werling LL, McMahon PN, Cox BM (1989) Selective changes in $\mu$ opioid receptor propertics induced by chronic morphine exposure. Proc Natl Acad Sci USA 86:6393-6397.

Williams JT, North RA (1984) Opiate-receptor interactions on single locus coeruleus neurones. Mol Pharmacol 26:489-497.

Williams JT, Egan TM, North RA (1982) Enkephalin opens potassium channels on mammalian central neurons. Nature 299:74-77.

Williams JT, North RA, Shefner SA, Nishi S, Egan TM (1984) Membrane properties of rat locus coeruleus neurons. Neuroscience 13:137-156.

Williams JT, North RA, Tokimasa T (1988) Inward rectification of resting and opioid-activated potassium currents in rat locus coeruleus neurons. J Neurosci 8:4299-4306. 